\title{
STRENGTH PARAMETER SELECTION IN STABILITY ANALYSIS OF RESIDUAL SOIL NAILED WALLS
}

\author{
Atefeh Asoudeh ${ }^{1}$ and Erwin $\mathrm{Oh}^{1}$ \\ ${ }^{1}$ School of Engineering, Griffith University, Australia
}

\begin{abstract}
This paper investigates slope stability of soil nailed walls which are located on sites formed with mostly residual soils. Residual soils, forming from weathered rocks can be found in many parts of the world with different characteristics and appearance based on type of the parent rock they have been formed of. A review on geotechnical properties of residual soils that have been used in previous studies in different parts of the world will be presented and then evaluated to be used as parameters for numerical analysis of soil nailed walls. Slope stability assessment is performed by LEM analysis and a discussion on the results of analysis is presented in this paper.
\end{abstract}

Keywords: Residual Soil, Slope Assessment, Soil Nailing, Numerical Analysis

\section{INTRODUCTION}

Slope stability is one of the most unpredictable problems in geotechnical projects and the cause of this unpredictability can be returned to ambiguity in several factors such as condition and location of failure, geotechnical parameters of soil and history of loading on the slope. This issue gets even more serious when the slope is on residual soil, which means that unlike sedimentary soils, the strength parameters of soil cannot be obtained trustfully based on stress-strain relationships.

Therefore, this paper tries to find a reliable solution in slope stability assessment of residual soil slopes by concentrating on selection of right values for strength parameters in this type of soil. First, a review on previous studies on residual soil slopes will be presented. Afterward, some samples of strength parameters for residual soils that have been used in previous studies will be introduced. Accordingly, critical geotechnical parameters that should be considered in assessment of a residual soil slope will be identified.

\section{A REVIEW ON RESIDUAL SOIL SLOPES}

Residual soils form from weathered rocks and can be found in many parts of the world with different characteristics and appearance based on the type of parent rock they have formed of. This large range of difference in residual soils leads to variety of studies that focus on different aspects of this type of soil and therefore in the following sections summary of these studies will be presented based on the area they are focusing on.

\subsection{General Characteristics of Residual Soils}

According to Townsend [1], three main chemical weathering factors that can lead to production of residual soils are: a) climate, b) parent rock's minerals and c) topography. Effect of climate in weathering is obvious as the rainfall provides the required moisture for chemical reactions and then the temperature dictates the chemical reaction's rate and considering these two components, best climate in which weathering can occur and therefore residual soils can be found is tropical weather.

The role of parent rock in weathering process is only predominant on initial stages of weathering and topography can influence the weathering procedure by controlling the surface run off and therefore moisture content of soil and also by rate of erosion.

Chin and Sew [2] highlighted the main traits of residual soils as very heterogeneous with high permeability. They summarized the importance of weathering profile regarding to its role in control of 1) potential failure surface and mode of failure 2) groundwater hydrology and 3) the erosion characteristics of material.

Valuable information regarding to general characteristics of residual soils has been gathered in the book prepared by Wesley [3]. In his book, Wesley presents basic aspects of residual soil and those properties that should be considered by geotechnical engineers while working with this type of soil.

By remarking some important characteristics of residual soils such as a) being heterogonous, b) having specific types of clay minerals and c) having 
unusual form of structure, Wesley concludes that in design of geotechnical structures on residual soil, engineers should give more attention to observation, experience and judgment instead of just relying on analytical and theoretical part of problem. Moreover, he emphasizes that application of e-log p graph for interpreting the behavior of residual soils is meaningless, as sedimentation process has not formed them.

\subsection{Engineering Properties of Residual Soils}

Townsend [1] also investigated the engineering properties of three different types of residual soil that are Lateritic Soils (highly weathered reddish tropical soils), Allophanic Soils (andosols, derived from volcanic ash) and Black Soil (or dark clays). Table 1 presented by Townsend [1] shows the shear strength parameters for the above-mentioned soils that had been obtained in previous studies.

Table 1 Example of Strength Parameters for Residual Soils, Townsend [1]

\begin{tabular}{|c|c|c|c|}
\hline $\begin{array}{l}\text { Soil Type \& } \\
\text { Location }\end{array}$ & $\varphi^{\prime}\left({ }^{\circ}\right)$ & $\begin{array}{c}\mathrm{c}^{\prime} \\
(\mathrm{kPa})\end{array}$ & Reference \\
\hline $\begin{array}{c}\text { Lateritic } \\
\text { gravels, Africa }\end{array}$ & 37.5 & $0-40$ & $\begin{array}{l}\text { Horn } \\
(1982 a)\end{array}$ \\
\hline $\begin{array}{c}\text { Lateritic clays, } \\
\text { Africa }\end{array}$ & 22.5 & $0-100$ & $\begin{array}{l}\text { Horn } \\
(1982 a)\end{array}$ \\
\hline $\begin{array}{l}\text { Lateritic soil, } \\
\text { Panama }\end{array}$ & 38 & 0 & $\begin{array}{c}\text { Townsend } \\
\text { (1970) }\end{array}$ \\
\hline $\begin{array}{c}\text { Granitic laterite } \\
\text { soil, } \\
\text { Venezuela }\end{array}$ & 21.5 & 20 & $\begin{array}{l}\text { Pursza } \\
\text { (1983) }\end{array}$ \\
\hline $\begin{array}{c}\text { Granitic } \\
\text { laterite, Brazil }\end{array}$ & 31 & 0 & $\begin{array}{l}\text { Vargas } \\
(1953)\end{array}$ \\
\hline Andosol, Java & 36 & 24 & $\begin{array}{l}\text { Wesley } \\
(1974)\end{array}$ \\
\hline $\begin{array}{l}\text { Black clay, } \\
\text { Cameroon }\end{array}$ & $6.1-20.1$ & $47-58$ & $\begin{array}{l}\text { Horn } \\
\text { (1982b) }\end{array}$ \\
\hline
\end{tabular}

Loganathan et al. [4] suggested a correlation factor for shear strength of residual soil in order to achieve more accurate results. This correlation factor can be applied into the laboratory shear strength of a specific type of residual soil that has been obtained by specific method of sampling and testing. For instance, the samples should be saturated under an effective stress of $10 \mathrm{Kpa}$ and shear strength parameters should be determined using multistage consolidated undrained triaxial tests using a strain rate of $0.05 \%$ per min.
Coutinho et al. [5] carried out a project to investigate the instability problems of a road constructed in Brazil after occurrence of a landslide in a natural non-homogenous unsaturated residual soil slope of this road. As a result of an intensive laboratory investigation, geotechnical parameters of residual soil were obtained and have been shown in Table 2.

Table 2 Strength parameters of residual soil by direct shear test, Coutinho et al. [5]

\begin{tabular}{|c|c|c|c|c|}
\hline $\begin{array}{c}\text { Soil } \\
\text { Type }\end{array}$ & $\begin{array}{c}\text { Depth } \\
\text { (m) }\end{array}$ & $\begin{array}{c}\text { Test } \\
\text { condition }\end{array}$ & $\varphi^{\prime}\left({ }^{\circ}\right)$ & $\begin{array}{c}c^{\prime} \\
(\mathrm{kPa})\end{array}$ \\
\hline \multirow{2}{*}{$\begin{array}{c}\text { Mature } \\
\text { Residual }\end{array}$} & \multirow{2}{*}{0.75} & Submerged & 31.9 & 10.8 \\
\hline & & Nat. M.C. & 41.6 & 71.4 \\
\hline \multirow{2}{*}{$\begin{array}{c}\text { Young } \\
\text { Residual }\end{array}$} & \multirow{2}{*}{8.70} & Submerged & 29.3 & 2.8 \\
\hline & & Nat. M.C. & 29.5 & 7.0 \\
\hline \multirow{2}{*}{$\begin{array}{c}\text { Mature } \\
\text { Residual } \\
\end{array}$} & \multirow{2}{*}{1.9} & Submerged & 35.5 & 0.0 \\
\hline & & Nat. M.C. & 37.8 & 15.8 \\
\hline \multirow{2}{*}{$\begin{array}{c}\text { Young } \\
\text { Residual }\end{array}$} & \multirow{2}{*}{4.6} & Submerged & 30.3 & 0.0 \\
\hline & & Nat. M.C. & 31.2 & 38.3 \\
\hline
\end{tabular}

Azevedo et al. [6] performed an extensive laboratory work on undisturbed samples of residual soils and used the results of these tests in modeling the behavior of residual soils with non-associated elastoplastic model in finite element analysis of a tunnel excavation. They compared the results of numerical analysis with both empirical predictions and field instrumentations and proposed coefficients that can be used in numerical simulation of tunnel construction stages in residual soils.

A series of examinations were conducted by Rahardjo et al. [7] in Singapore to specify the relationship between the degree of weathering and soil behavior in residual soils. As a result, they found that the higher the degree of weathering is, the more pore volume is which means a larger range of pore-size distribution.

As a part of their work, they took samples from different depths corresponding to different degrees of weathering and conducted consolidated, drained tri-axial compression tests under both saturated and unsaturated. Table 3 shows the summary of data that they found as a result of the above-mentioned tests.

Rahman et al. [8] performed a testing program on reinforced and unreinforced residual soil samples by considering six different stress strain paths. Then, they introduced parameters related to the Cam Clay model in simulating the finite element analysis of reinforced residual soil and as a result they could 
find a good agreement between the result of their numerical simulations and measured response.

Table 3 Shear strength of residual soil in different depths, Rahardjo et al. [7]

\begin{tabular}{|l|c|c|c|c|}
\hline \multicolumn{1}{|c|}{ Soil Type } & $\begin{array}{c}\text { Depth } \\
(\mathbf{m})\end{array}$ & $\begin{array}{c}\text { Grade of } \\
\text { Weathering }\end{array}$ & $\begin{array}{c}\mathbf{\varphi}^{\prime} \\
\mathbf{(}^{\circ}\end{array}$ & $\begin{array}{c}\mathbf{c} \\
\mathbf{( k P a )}\end{array}$ \\
\hline Granitic Bukit Timah formation \\
\hline Sandy Silt & $5-9$ & VI & 27 & 26 \\
\hline Silty Sand & $10-15$ & V & 35 & 13 \\
\hline Silty Sand & $15-21$ & V & 38 & 12 \\
\hline Sedimentary Jurong formation \\
\hline Purple silty sand & $3-4$ & IV & 42 & 125 \\
\hline Purple silty sand & $4-5$ & IV & 51 & 55 \\
\hline Orange silty sand & $9-10$ & IV & 45 & 35 \\
\hline Purple silty sand & $22-24$ & III & 50 & 225 \\
\hline
\end{tabular}

Ogunro et al. [9] presented the geotechnical properties of Piedmont residual soil on which some major cities and centers in the east coast of U.S. are founded and it is the result of chemical and mechanical weathering of Piedmont Palezoic Rocks (schist, gneiss, and granite). Table 4 shows a sample of results from Borehole Shear Test (BST) and CU triaxial test in a site located in North Carolina.

Table 4 Sample of result from BST and CU triaxial test for Piedmont residual soil, Ogunro et al. [9]

\begin{tabular}{|c|c|c|c|c|c|}
\hline \multirow{2}{*}{ Borehole\# } & \multirow{2}{*}{$\begin{array}{c}\text { Depth } \\
\text { (m) }\end{array}$} & \multicolumn{2}{|c|}{$\begin{array}{c}\text { Borehole } \\
\text { Shear Test } \\
\text { (BST) }\end{array}$} & \multicolumn{2}{|c|}{$\begin{array}{c}\text { CU triaxial } \\
\text { Test }\end{array}$} \\
\hline & & $\varphi^{\prime}\left(^{\circ}\right)$ & $\begin{array}{c}\mathbf{c}^{\prime} \\
(\mathbf{k P a})\end{array}$ & $\begin{array}{l}\varphi^{\prime} \\
\left({ }^{\circ}\right)\end{array}$ & $\begin{array}{c}\mathrm{c}^{\prime} \\
(\mathrm{kPa})\end{array}$ \\
\hline \multirow{3}{*}{1} & 10 & 45 & 0 & 29 & 5.9 \\
\hline & 15 & 43 & 0 & 37 & 11 \\
\hline & 20 & 40 & 9.65 & 41 & 0 \\
\hline \multirow{4}{*}{2} & 5 & 44 & 0 & 30 & 24.1 \\
\hline & 10 & 23 & 7.9 & 30 & 18.3 \\
\hline & 15 & 40 & 0 & 36 & 14.1 \\
\hline & 20 & 42 & 6.9 & 29 & 20 \\
\hline
\end{tabular}

In another paper, Anderson and Cottingham [10] introduced the average values for drained Cohesion and friction angle of Piedmont residual soil equal to $26.9 \mathrm{kPa}$ and 26.3 degree, respectively.

Huat et al. [11] collected lots of data and in their book, presented an overview of the index and engineering properties of some tropical residual soils. Based on their findings, values for soil strength in residual soils ranges from 2 to $123 \mathrm{KN} / \mathrm{m}^{2}$ for cohesion and 10 to 58 for friction angle $(\varphi)$. They related this large range of variety to the great difference of soil formation in residual soils.

Furthermore, Wesley [3] related the high shear strength of these soils to existence of clay minerals. Also, microstructural effect and its contribution to the cohesive component of shear strength (c) can be chosen as another reason for the high shear strength of these soils.

\subsection{Slope Stability on Residual Soils}

There are several studies that have been carried out to study the stability of slopes in residual soil areas in different parts of the world and the following paragraphs is a brief on some of these studies.

One important part of work carried out by Coutinho et al. [5], was a back analysis in order to find the shear strength parameters of residual soil that can lead to the slope failure. As a result they concluded that shear strength parameters obtained from laboratory tests could explain the failure condition ( $F o S=1$ ) by considering a low or very low amount of suction in wet seasoning.

Moreover, they introduced several factors as the impacting factors on the landslide including excavation for the purpose of road construction, sever rainfalls and prolonged high precipitation.

Tan et al. [12] performed a parametric study on stability analysis of residual soil slopes in Malaysia and investigated the effect of several factors such as slope geometry, soil parameters, piezometric surface, surcharge and soil nailing reinforcement on the tropical residual soil slope stability. However, the summary of their work does not show any sign of considering specific characteristics for residual soil and therefore, residual soil has been treated and analyzed in the same way that sedimentary soil is examined.

Another important study on residual soil slopes is a section of book prepared by Huat et al. [11] on failure of 6 slopes (including natural, man-made and filled slopes) on tropical residual weathered soil located in different parts of Malaysia. As a result of this study they recommended the use of Consolidated Isotropically Undrained (C.I.U.) triaxial test in obtaining the peak shear strength and use of ring shear test to find the residual shear strength and they suggested the use of residual strength in residual soil slope stability design. 


\subsection{Discussion and Concluding Remarks From Previous Studies}

One important point that can be concluded from previous section is that almost all types of the residual soils that have been studied possess a relatively high value of friction angle $(\varphi)$ with a minimum record of 20 degrees and average value of 35 degrees. Unlike friction angle, cohesion of residual soils has shown a wide range of values in different studies from zero to very high values near to $200 \mathrm{kPa}$ in deeper distances from ground level. This important fact demands a crucial attention to impact of cohesion on stability of residual soil slopes. Therefore, a parametric study has been performed and three different cases (Case-I: $\varphi=20^{\circ}$, Case-II: $\varphi=35^{\circ}$, Case-III: $\varphi=45^{\circ}$ ) were used to investigate the effect of different values of cohesion on stability of nailed slopes in residual soils. It should be noted that cohesion and friction angle that are used in this study are those obtained from drained condition. Next sections present a summary on detail of slope assessment and results of Limit Equilibrium Method (LEM) of analysis performed by geotechnical software Geo-Slope for the abovementioned cases.

\section{NUMERICAL ANALYSIS OF DIFFERENT SLOPES IN RESIDUAL SOILS}

Three different cases with three different values of friction angle $\left(\varphi=20^{\circ}, 35^{\circ} \& 45^{\circ}\right)$ were simulated in geotechnical software Geo-slope, which uses Limit Equilibrium Method (LEM) in slope stability analysis. Geometrical properties of slopes and general properties of soil nails were identical for all three cases and it has been presented in Fig.1

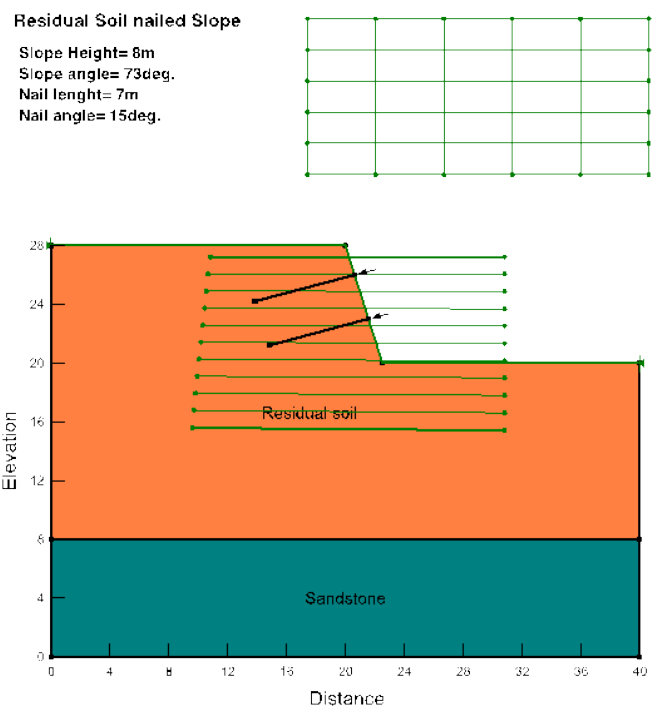

Fig.1 Geometry of modeled soil nailed slope
As shown in Fig.1, two rows of nails with length of $7 \mathrm{~m}$, angle of $15^{\circ}$ and horizontal space of $2 \mathrm{~m}$ were considered in stabilization of slope. The hole diameter for nails is $150 \mathrm{~mm}$ and the nails diameter is $28 \mathrm{~mm}$. In order to find the FoS of slopes method of Morgenstern-Price, which is able to satisfy both force and moment equilibriums, was used in LEM analysis.

\section{RESULT OF ANALYSIS AND DISCUSSION}

In order to examine the impact of cohesion value (c') on stability of these slopes, a sensitivity check was performed and the obtained Factor of Safety (FoS) for each case has been presented in Fig.2. For the purpose of sensitivity check, a wide range of cohesion changing from zero to $100 \mathrm{kPa}$ was assumed for the cohesion parameter of slopes.

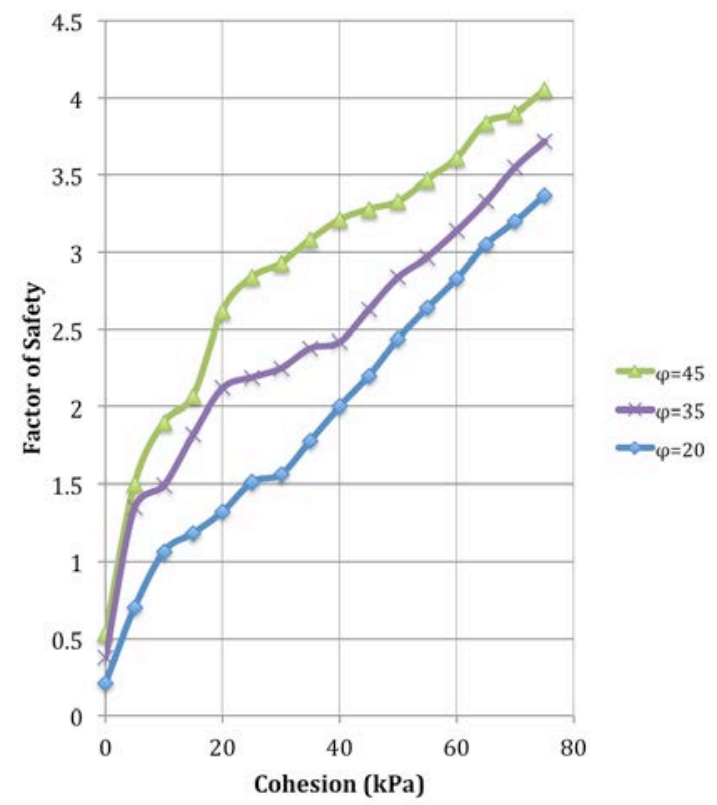

Fig.2 FoS of nailed slope for different values of cohesion

According to the result of analysis presented in Fig.2 , a nearly linear relationship exists between FoS and cohesion of soil and the slope of this line is almost the same for all three cases. However, this relationship is more variable in low values of cohesion and almost in all three cases the cohesion value of less than $10 \mathrm{kPa}$ will lead to unacceptable FoS, which is less than 1.5. For Slopes with friction angle of 20 degrees, the minimum cohesion leading to the acceptable FoS (which should be more than 1.5 ) is $25 \mathrm{kPa}$.

\section{CONCLUSION}

A review of previous studies on residual soils and specifically residual soil slopes was presented in this paper and strength parameters of soil which had been considered in each study was presented in 
separate tables. Based on assumed strength parameters in previous works, three different cases were modeled and analyzed to investigate the impact of cohesion on residual soil slopes. As a result, findings of the present study demonstrated that residual soil slopes with cohesion parameter of less than $10 \mathrm{kPa}$ (no matter how much is the friction angle) and with acceptable amount of reinforcement have the high probability of collapse and these types of slopes are sensitive to value of cohesion. Also, it can be concluded that more attention needs to be taken in finding the cohesion parameter of residual soils especially when dealing with residual soils possessing low cohesion.

\section{REFERENCES}

1. Townsend, F., Geotechnical Characteristics of Residual Soils. Journal of Geotechnical Engineering, 1985. 111(1): p. 77-94.

2. Chin, I.T.Y. and I.D.G.S. Sew, THE DETERMINATION OF SHEAR STRENGTH IN RESIDUAL SOILS FOR SLOPE STABILITY ANALYSIS, in Seminar Cerun Kebangsaan2001: Cameron Highlands, Malaysia.

3. Wesley, L.D., Geotechnical Engineering in Residual Soils. 2012: Wiley.

4. Loganathan, N., S. de Silva, and A. Thurairajah, Strength Correlation Factor for Residual Soils. Journal of Geotechnical Engineering, 1992. 118(4): p. 593-610.

5. Coutinho, R.Q., J.B.S. Neto, and F.Q. Costa, Design Strength Parameters of a Slope on Unsaturated Gneissic Residual Soil, in Advances in Unsaturated Geotechnics. 2000. p. 247-261.

6. Azevedo, R., A. Parreira, and J. Zornberg, Numerical Analysis of a Tunnel in Residual Soils. Journal of Geotechnical and Geoenvironmental Engineering, 2002. 128(3): p. 227-236.
7. Rahardjo, H., K.K. Aung, E.C. Leong, and R.B. Rezaur, Characteristics of residual soils in Singapore as formed by weathering. Engineering Geology, 2004. 73: p. 12.

8. Rahman, M.M., S.A. Mofiz, and M.R. Taha, Experiments and Finite Element Analysis of Geosynthetics Reinforced Residual Soil, in Slopes and Retaining Structures Under Seismic and Static Conditions. 2005. p. 1-12.

9. Ogunro, V.O., B.J. Anderson, J. James Starnes, and R. Burrage, Characterization and Geotechnical Properties of Piedmont Residual Soils, in GeoCongress 2008. 2008. p. 44-51.

10. Anderson, J.B. and M.A. Cottingham, Results of Consolidated Drained Triaxial Tests on Granitic Residual Soil, in Contemporary Topics in In Situ Testing, Analysis, and Reliability of Foundations. 2009. p. 74-78.

11. Huat, B.B.K., D. G.Toll, and A. Prasad, Handbook of Tropical Residual Soils Engineering. 2012: CRC Press/Balkema.

12. Tan, L.P., C.Y. Lee, and T. Sivadass. Parametric studies of stability of residual soil slopes. in ICCBT. 2008. Malaysia.

Int. J. of GEOMATE, Sept., 2014, Vol. 7, No. 1 (Sl. No. 13), pp. 950-954.

MS No. 3213 received on Sept. 11, 2013 and reviewed under GEOMATE publication policies. Copyright (C) 2014, International Journal of GEOMATE. All rights reserved, including the making of copies unless permission is obtained from the copyright proprietors. Pertinent discussion including authors' closure, if any, will be published in the Sept. 2015 if the discussion is received by March 2015.

Corresponding Author: Atefeh Asoudeh

